\title{
„The Control” in View of International Accounting Regulation and Romanian Accounting Regulation
}

\author{
Cristina Ciuraru-Andrica, „Vasile Alecsandri” University of Bacău, Romania \\ Elena Oprişan, „Vasile Alecsandri” University of Bacău, Romania
}

\begin{abstract}
Summary
In Romania, financial reporting accountant is governed by Accounting Low number 82/1991, republished, and O.M.F.P. 3.055/2009 approving the accounting regulation in accordance with European Directives. To these are added the International Financial Reporting Standards (IFRS, IAS and IFRIC) of which must take into account certain Romanian legal persons in accordance with applicable regulations. Therefore this paper presents the main points of the control from the two types of accounting regulations perspective (national and international) applied in our country.
\end{abstract}

\section{Keywords}

Control, exclusive control, parent, subsidiary, acquirer, acquiree

JEL Code: M41

\section{Introduction}

The control exercised by an entity over another entity has special implications in accounting plan, but not only.

In first place, the entities form a group or a business combination. The group, in accounting terms, includes besides the controlled entities, also the entities on which parent exercises a common control or a significant influence. However, in this few lines we will stop only on control, conditions of its existing and the consequences arising from its manifestation.

In second place, we have to delimit the consolidation perimeter to establish those entities which are capable of being consolidated, in the sense that its separate financial statements will be the bases for preparing consolidated financial statements. So the group (precisely the parent) must prepare a distinct set of financial statements (with some exceptions) whose objective is to satisfy the user needs.

Accounting regulations applicable to solve the two issues, mentioned above, differ depending on the area where the group is manifesting and on the legal obligation to which it must submit to.

So, in our country, according to accounting regulations of the O.M.F.P. 3.055/2.009 ${ }^{1}$, the entities that are part of the category of legal persons of public interest ${ }^{2}$ (with

${ }^{1}$ O.M.F.P. nr. 3.055/2009 for approval of accounting regulations with European Directives published in the M.O. nb. 766 from 10 November 2009, art. 14

${ }_{2}$ According to art. 33 alin. (2) from Accountant Law nr. 82/1991, republished, legal persons of public interest are: credit institutions; non-bank financial institution, defined according to legal regulations, written in general register; insurance, insurance-reinsurance and reinsurance companies; authorized entities regulated and supervised by the 
exception the entities of which securities are traded on a regulated market, credit institutions and non-bank financial institution, defined according to legal regulations, written in general register, insurance, insurance-reinsurance and reinsurance companies, association of pension, the financial investment services companies, management of investment companies and collective investment undertakings) and other legal persons which must prepare consolidated annual financial statements, can prepare the statements either based on Directive VII of the European Economic Community, either based on the International Financial Reporting Standards. This option suits especially multinational groups which do not have to prepare two sets of financial statements (national and international). However, they do not escape the fact that the separate financial statements of the entities which form the group, must be prepared both in accordance with national and international accounting regulations. Therefore, the present paper, shows the control key points from the perspective of the two regulatory and standardization bodies (the Ministry of Public Finance - in the case of national accounting rules and International Accounting Standards Board, in the case of the international ones).

\section{„The Control” in View of International Accounting Regulation}

According to International Accounting Standards (principal: IFRS 3 ,Business Combination”, IAS 24 „Related Party Disclosure”, IAS 27 „Consolidated and Separate Financial Statements”, IAS 28 ,Investments in Associates” and IAS 31 „Interest in Joint Ventures") control represents the power to govern the financial and operating policies of an entity, named subsidiary, to obtain benefits from its activities. A subsidiary is an entity, including an unincorporated unit as a partnership, which is controlled by another entity (named parent - defined as an entity that has one or more subsidiaries).

The term control, used by the international accounting rules, in fact is availed to denote the excusive control. This consists in the capacity of the parent to rule directly or indirectly an subsidiary, being able to fully decide other its activity. In literature, exclusive control knows several forms of exercise: exclusive right control and exclusive fact control. To these two, some authors add a third form of exclusive control manifestation named exclusive contractual or statutory control.

Basically:

- exclusive right control occurs when the parent holds, directly or indirectly, over $50 \%$ from voting rights of the subsidiary;

- exclusive fact control occurs when the parent has the power to appoint or remove a majority of the subsidiary governing bodies;

- exclusive contractual or statutory control results when the power of the parent to establish the financial and operating policies of an subsidiary derivers from a contractual or statutory clause or from an agreement.

International rules stipulate that a parent must consolidate its investments into a subsidiary, to prepare its consolidate financial statements. Therefore, IAS 27 shall be applied in the preparation and presentation of consolidated financial statements for a group of entities under the control of a parent.

Supervisory Committee of the Private Pension System; the financial investment services companies, management of investment companies and collective investment undertakings, authorized and approved by the National Security Committee; the entities of which securities are traded on a regulated market; national companies; legal persons which belong to a group of companies and enters the consolidation perimeter by a parent who applies the International Financial Reporting Standards 
According to the standard, it is assumed there is control when the parent holds, directly or indirectly, in subsidiaries, more than half the number of votes (exclusive control), except exceptional cases in which can be proved that this kind of propriety is not control. Control also exists when the parent holds half or less of the voting power of an subsidiary when there is:

a) power over more than half of the voting rights by virtue of an agreement with other investors (exclusive contractual or statutory control);

$\mathrm{b}$ power to govern the financial and operating policies of the entity under a statute or an agreement (exclusive contractual or statutory control);

c) power to appoint or remove the majority of the members of the board of directors or equivalent governing body and control of the entity is by that board or body (exclusive fact control); or

d) power to cast the majority of votes at meetings of the board of directors or equivalent governing body and control of the entity is by that board or body (exclusive fact control).

To establish control are taken into consideration also the potential voting rights related to share warrants, share call options, debt or equity instruments that are convertible into ordinary shares, or other similar instruments that have the potential, if exercised or converted, to give the entity voting power or reduce another party's voting power over the financial and operating policies of another entity. Potential voting rights are not currently exercisable or convertible when, for example, they cannot be exercised or converted until a future date or until the occurrence of a future event.

In assessing whether potential voting rights contribute to control, the entity examines all facts and circumstances (including the terms of exercise of the potential voting rights and any other contractual arrangements whether considered individually or in combination) that affect potential voting rights, except the intention of management and the financial ability to exercise or convert such rights.

So basically, the exercise of exclusive control requires the possession of the majority of voting rights, but due to absenteeism of small shareholders in General Assemblies and the existence of shares with different voting rights (double or deprived voting shares) exists the possibility that a stake below $50 \%$ to be enough to acquire control. Example: The parent owns 35\% of the stoke in a subsidiary - double voting right shares. $15 \%$ of the subsidiary stoke represents deprived voting shares (potential voting rights).Even if the parent percentage of ownership is only 35\% (named interest rate), it exercises control (expressed through voting rights in General Assemblies) in percentage of $58,33 \%{ }^{3}$ (named control rate), so an exclusive control. Therefore, control can or can not be the consequence of property relationship. In perspective of IFRS 3 "Business Combination" control can occur also in these situations:

a) by transferring cash, cash equivalents or other assets (including net assets that constitute a business);

b) by incurring liabilities;

c) by issuing equity interests;

d) by providing more than one type of consideration; or

e) without transferring consideration, including by contract alone (example: The acquire repurchases a sufficient number of its own shares for an existing investor (the acquirer) to obtain control ; minority veto rights lapse that previously kept the acquirer from controlling an acquire in which the acquirer held the majority voting rights)

Also control may exist under the influence of pertinent factors and circumstances as

\footnotetext{
${ }^{3}$ Percentage is obtained after calculation: $(35 * 2) /(35 * 2+50)$
} 
a) the relative voting rights in the combined entity after the business combination (the control belongs to the combining entity whose owners as a group retain or receive the largest portion of the voting rights in the combined entity; in determining which group of owners retains or receives the largest portion of the voting rights, an entity shall consider the existence of any unusual or special voting arrangements and options, warrants or convertible securities. - exclusive right control);

b) the existence of a large minority voting interest in the combined entity if no other owner or organised group of owners has a significant voting interest (The control is hold by the combining entity whose single owner or organised group of owners holds the largest minority voting interest in the combined entity - exclusive right control);

c) the composition of the governing body of the combined entity (The control is exercised by the combining entity whose owners have the ability to elect or appoint or to remove a majority of the members of the governing body of the combined entity exclusive fact control).

The parent defined by the IAS 27, according to IFRS 3 is named acquirer. It is the entity that obtains control of another entity named the acquiree (according to IAS 27 subsidiary). The mentioned IFRS defines a business combination as a transaction or other event in which an acquirer obtains control of one or more businesses.

The control exercised over another entity can be achieved in stages.

Example: On 31 December N, S.C. „Alfa” owns 25\% of S.C. „Beta” shares. On that date, S.C. „Alfa” buys another $35 \%$ of S.C. „Beta” shares, that gives it the right to control aver SC „Beta”. According to IFRS 3 this transaction is named a business combination achieved in stages.

Sometimes the existence of control according to one of the ways listed above is temporary. So the parent can lose control over a subsidiary with or without a change in absolute or relative ownership levels. This could occur, for example, when a subsidiary becomes subject to the control of a government, court, administrator or regulator. It also could occur as a result of a contractual agreement. (or of time of expiration being previously concluded) or from the sale of an interest in equity or when the subsidiary issue new interests in equity to third parties.

More as in some cases control can be achieved in stages, as its loss, sometimes, it can be the result of several transaction (arrangements). In all this cases the parent lose the capacity to govern the financial and operating policies of the entity, and all benefits that would have resulted from these.

Also the existing of control implies the determination of the application area of consolidated financial statements (according to IAS 27) or of the consolidation perimeter, as it is named in literature (composed exclusively of consolidated companies or included in consolidation).

If recently, according to IAS 27 , the subsidiaries over which a temporary control is exercised (as a result of ownership of their shares for sale only) and those severely restricted which affect the ability to transfer funds to parent, were excluded from the perimeter, in present this exemptions are eliminated.

So, the rule is that all subsidiaries must be consolidated.

Justification for this rule stands in:

- subsidiary problem acquired with the intention of sale within twelve months and for which the management actively search a buyer, must be treated according to IFRS 5 "Non-Current Assets Held for Sale and Discontinued Operations" - the subsidiary which operate under severe restriction are also consolidated on the grounds that these circumstances do not exclude control.

\section{"The control" in View of Romanian Accounting Regulation}


Romanian accounting regulations requires the parent company conditions that must be accomplished to exercise exclusive control over an entity (subsidiary):

a) to own the majority of the voting rights (exclusive right control);

b) to be a shareholder or a member of the entity and that the majority of members of the administration, management and supervision that have accomplished these functions during the financial year, during the previous financial year and until the annual consolidated financial statements, to be appointed only as a result of exercising its voting rights (exclusive fact control);

c) to be a shareholder or a associates of the entity and to be the only one that holds control over the majority of the voting rights or because of an agreement with over shareholders or associates (exclusive contractual or statutory control);

d) to be a shareholder or an associate of the subsidiary and to have the right to exercise a notable influence over it, under a contract signed with the concerned entity or a clause in the memorandum or subsidiary status if applicable law permits such contracts or clauses (exclusive contractual or statutory control);

e) to have the power to exercise or to effectively exercise a notable influence or control over a subsidiary (exclusive right control);

f) to be a shareholder or an associate of the subsidiary and to have the power to appoint or remove the majority of the subsidiaries administration, management and supervision members (exclusive fact control);

g) to rule on an unified basis the parent company and its subsidiary (any of the three types of exclusive control).

As in international regulations, to evaluate if an entity hold control are taken into consideration also the potential voting rights but not the intention of management and its financial capacity to exercise or convert such rights.

Example: Entities A and B holds $45 \%$, respective $30 \%$ of the ordinary shares, with voting rights, over entity $\mathrm{C}$. The others shares have been dealt to a large number of shareholders who do not participate into decision. Entity B also owns options which are exercisable at any time and if it would be exercised would give it the right of exclusive control over entity C. However, the entity B does not intend to exercise them. This situation does not change the fact that the parent of entity $\mathrm{C}$ is entity $\mathrm{B}$ and not $\mathrm{A}$, as we are tempted to think.

We observe that in Romanian accounting regulations the term of exclusive control is found also under the name of dominant/notable influence as under the simple term of control. Even if this regulations does not present any definition of control, from the conditions that must be accomplished to exist control, we deduce that in principle represents the power of the parent over the subsidiary reflected by the voting rights and manifested by unilateral and firm decisions on its activity.

As specified above the existing of control implies the dimensioning of the consolidated perimeter.

O.M.F.P. 3.055/2.009 stipulates that the parent and all its subsidiaries must be consolidated, that is to be included into the consolidated perimeter. To this rule there are exceptions. So, an entity can be excluded from consolidation and implicit from the perimeter in these situations:

- inclusion is not significant for the purpose of giving a faire picture of assets, debts, of the financial position and profit or loss of entities included into the consolidated financial statements (however if two or more of the entities satisfy this requirement it must be included into annual consolidated financial statements, if considered as a whole it is significant for the purpose of providing a faire image);

- severe restrictions on long term stops the parent to exercise its rights over the assets or the entity management;

- the needed information for preparing the annual consolidated financial statements can be obtained only with undue costs or delays; 
- the entities shares are held exclusively for subsequent sale.

\section{Conclusions}

The existing of control represents a significant economic event that warrants a change from the investments accounting to the consolidation, from individual financial statement to the consolidated financial statements.

In view of the two accounting regulations, national and international, the control has in principle as object the share that carries the voting right. Control its the symbol of power exercised by the parent/acquirer over the activity of the subsidiary/acquiree and manifested through supervision and guidance.

Exercising control implies the establishing of the consolidation perimeter. In its delimitation the regulatory bodies have different opinions. While the international standards do not provide any exceptions from the subsidiary consolidation including them all, in the consolidation perimeter, the Romanian Regulations shows several instances of exclusion of subsidiaries from consolidation. These differences may have special implications on the consolidated financial statements (and implicit on users) related to comparability and pertinent financial and economic analysis. Likely that harmonization will lead the ongoing attempts to alleviate these discrepancies and to unique the accountant language "spoken" by the financial statements.

Control gives rise to power relation on which always participates the parent (acquirer, dominant, consolidated) company on the one hand, and one or more subsidiaries (acquiree, consolidate, daughter) company on the over hand, whose "product" is the consolidated financial statements.

\section{Bibliografie}

1. Deju M. (2008), Contabilitate aprofundată. Concepte, modele, studii de caz, Ed. Alma Mater, Bacău

2. Fundația Comitetului pentru Standarde Internaționale de Contabilitate (2009), Standardele internaționale de raportare financiară: IFRS: norme oficiale emise la 1 ianuarie 2009, Ediția a 4-a, revizuită, Ed. CECCAR, București

3. Gîrbină M., Bunea $\square$. (2008), Sinteze, studii de caz şi teste grilă privind aplicarea IAS (revizuite) - IFRS, Ed. CECCAR, București

4. Malciu L. Feleagă N. (2004), Reglementare şi practici de consolidare a conturilor: din orele astrale ale Eurepei Contabile, Ed. CECCAR, Bucureşti

5. Pitulice C. (2007), Teorie şi practică privind grupurile de societăți şi situațiile financiare consolidate, Ed. Contaplus, Ploiești

6. Popa A., Pitulice C., Jianu I., Nichita M. (2007), Studii practice privind aplicarea standardelor internaționale de raportare financiară în România, Ed. Contaplus, Ploieşti

7. Săcărin M. (2001), Contabilitatea grupurilor multinaționale, Ed. Economică, Bucureşti

8. Ordinul Ministerului Finanţelor Publice nr. 3.055/2009 pentru aprobarea reglementărilor contabile conforme cu directivele europene publicat în Monitorul Oficial nr. 766 din 10 noiembrie 2009

9. http://www.iasb.org 